\title{
Human Rights of Arrested Person in Ancient India: An Appraisal
}

\author{
Dr. D.P.Verma*, Dr. Ramesh Chandra Chhajta (HPS)** \\ *Associate Professor Law HPU Regional Centre Dharamshala \\ **Superintendent of Police. Solan, HP
}

\begin{abstract}
The criminal administration of justice is one of the important components of the State. It has the dual responsibility of protection as well as detection of crime in society. The criminal administration of justice in India assumes that the State as a prosecution using its investigating resources and employing competent prosecutors will try its best to prove the case while on the other hand accused will hire the equally competent services of a counsel to defend himself and challenge the accusations leveled against him. While implementing the criminal law, one thing which is very important, is to make a balance between the society on one hand and individual liberty on the other. Therefore an individual require personal liberty and social security both as fundamental guarantee and need respectively. One of the processes that impose a major threat to the liberty of the individual is that of arrest. .Arrest involves restriction of liberty of a person arrested and therefore, infringes the basic human rights of liberty. Nevertheless the Constitution of India as well as International human rights law recognizes the power of the State to arrest any person as a part of its primary role of maintaining law and order. The practice prevailed in Ancient times as well. Humanity requires a just, fair and reasonable procedure with all human beings, be it an arrested person or others. Hence, present paper is an attempt to study that whether arrested person had any rights in ancient India or not?
\end{abstract}

\section{Introduction}

Human rights are norms that help to protect all people everywhere from severe political, legal, and social abuses. Human rights are rights inherent to all human beings, whatever our nationality, place of residence, sex, national or ethnic origin, colour, religion, language, or any other status. We are all equally entitled to our human rights without discrimination. Since the evolution of a civilized society a man has aimed at creating humane society and this is an age old desire embedded in its very nature. The concept continued to develop even with the development of society and evolution of State. No doubt, the concept of government had changed from ancient period to current state of civilization routing through many channels. A primary purpose of any government was to enforce law and order throughout ages and it persists in modern context also. The Centre and the State governments of India, for example, grant certain powers to government officials so that they can maintain an orderly society and protect the lives, property and rights of the people. These governmental agencies have the duty of preventing some individuals from harming others through some acts designated as crime. There are, however, constitutional limits on the power of government officials in order to prevent them from abusing the rights of individuals, including those accused of criminal behavior. Here a question arises that whether accused or arrested persons have any rights or not? The answer lies in the presumption that "It is better for 99 guilty persons to go free than for one innocent person to be punished." Hence the present paper is an attempt to study and discuss human rights of arrested persons in ancient India. The study based on secondary data which has been collected from different books, journal, scholarly papers and articles and also websites having direct bearing on the topic.

\section{Laws in Ancient India}

Like in every civilized society, socio-economic and political conditions prevailing during different phases of the history of India influenced its evolution of law. Accordingly, the objectives of the criminal justice and methods of its administration changed from time to time and from one period of history to another. The rulers at different times had different setup of administration of justice. Initially, the Law or Dharma, as propounded in the Vedas was considered supreme in ancient India for the King had no legislative power. But gradually, this situation changed and the King started making laws and regulations keeping in view the customs and local usages. There is no doubt that in early history of ancient India Hindu law dominated which was based on Hinduism. Hinduism was a way of life with considerable freedom of belief. It was a family of four Vedas, eighteen Puranas, one hundred \& eight Upnishads, two epics (Mahabharta and Ramayana), various Neetis, Bhagavad Gita, Manu Samhita (or Smiriti); comparatively recent Kautilya's Arthshastra and other big and small texts with regional flavours of the same grand narration to which the concept of dharma remained central. The concept of Dharma or law in ancient India was inspired by the Vedas which contained rules of conduct and rites compiled in Dharma Sutras, which were being practiced in a number of branches of the Vedic schools. The earliest document throwing light on the 
theory of jurisprudence, which forms part of practical governance, is the Arthashastra of Kautilya dating back to 300 B.C. After coming into existence of Christian era, there evolved a number of Dharmashastras which dealt extensively with Dharma like, Manu, Yajnavalkya, Narda and Parashara smiritis etc. The authority of dharma, which was moral and not legal, was kept alive by Indian scholars and jurists called Brahmins, however, the King through royal decree could translate dharma into law.

The Vedas were an act of revealing or communicating divine truth or revealed texts gathered directly by inspired savants or rishis. Different schools have interpreted the philosophy of Vedas but the Vedas themselves did not contain any prescriptive rules of behaviour, but only 'references to usage' which constituted dharma, commentaries and treatises contained numerous precepts, which prescribed rules for governing behaviour.

Generally Dharma was supposed to override the all other sources of law but Kautilya's Arthshastra mentions Royal commands were the supreme. Therefore the state performed its duty of protection of society and the individual through coercive enforcement of the standards of justice, which are reduced for the purpose into the ins and outs of positive law known as behaviour (vyavahaara). Early codes of law, covering every aspect of life, are preserved in the voluminous Dharmashastras literature, of which perhaps the Laws of Manu is the most wellknown.

\section{Administration of Justice}

So long as the territory was small, the form of administration was more or less democratic; but as the size of the territory grew large, it was found necessary to adopt a system in which political powers were concentrated in the hands of the Head of the State assisted by a Council of Ministers and a trained bureaucracy. In many ancient Countries the State, in the earlier stages of its development, was theocratic; but in India, although the social organisation contained within its bosom the Brahmanic theocracy and was to a large extent dominated by it, the State itself never became a theocracy in the proper sense of the term. This becomes evident when we consider a few broad facts. First, the ruler was never regarded as the head of religion. Secondly, the primary object of the State was not spiritual salvation, but social well-being. Thirdly, law, mingled as it was with religion and morality, was the chief source of the authority of the State. And lastly, the political status of individuals was independent of their religious beliefs and convictions. The sphere of State-action was in the earliest period very limited. The State was then, in fact, what political scientists' term a Police-State. Therefore in nutshell it can be asserted that in ancient India the King was the law giver and as consequence of struggle for political power between king and people the royal authority was denuded of its powers of law giving.

From the Vedic period onward, the perennial attitude of Indian culture has been that justice and righteousness among men are microcosmic reflections of the natural order and harmony of the macrocosmic universe. The cosmos is instinct with an inherent structure and functional pattern in which men at their best willingly participate. Justice, then, in the Indian context, is a human expression of a wider universal principle of nature and if man was entirely true to nature; his actions would be spontaneously just. Justice, in the sense of a distributive equity, was experienced by men in three major guises: as moral justice, social justice and legal justice. The individual required maintenance, protection and help even for spiritual realization and therefore, the economic, political and legal organizations of society are deemed necessary. It is the duty of the ideal state to create conditions and opportunities that will gradually help man overcome his ignorance, selfishness, and immoral tendencies, so that a harmonious community may evolve in which every individual can advance toward the supreme goal of spiritual freedom from ignorance and selfishness and all the vices that follow there from.

Administration of justice did not form the part of state's duty in early times. The aggrieved party had to take recourse to get his wrong redressed. In India we also find that authorities like Manusmriti, recognising the use of force, stratagem, dharna by the plaintiff as a normal mode of redressal even when the law courts had been established .For a long time even murders were not regarded as offence against state but as simple torts, where mere compensation had to be given to the relative of the deceased party. Manu, as a realist, insists in his discussion of the role of the king that if he does not inflict punishment on those worthy to be punished, the stronger would roast the weaker like fish on a spit. Having fully considered the time and the place (of the offence), the strength and knowledge (of the offender), let him justly inflict that punishment on men who act unjustly. The exercise of the coercive power of danda with regard to law-enforcement is considered just in the highest sense, since particularistic legal codes are considered to be concrete and detailed embodiments of the more abstract and illustrious principles of justice which are fundamental to the universe.

The laws regarding punishment were not uniform as it varied according to circumstances of the particular case and victims. It was only because of these reasons that the state later on decided to form laws to punish criminals and criminal adjudication started with the delegation of power to a commission to try criminal case in ancient Roman civilization. It was only in 149 BC that true criminal law came into existence with the appointment of permanent commission to hear or try criminal cases. The earlier criminal tribunals were just committees of legislature. The persons tried before one commission, were not to be tried before other commission for the same offences. This practice continued for long till Emperor handed over the criminal administration to the magistrates 
appointed directly and the place of senate was taken by Imperial Privy council which later on became court of Appeal. This Roman view was adopted by many civilizations.

\section{Crimes and Punishment in Ancient India}

In ancient India crimes against persons were adjudicated with reference to the class-status of the victim. The penalty for a crime was increasingly severe the higher the varna of the victim. The same underlying idea is reflected more positively in the legal administration of Indian justice through the notion that the more elevated a man is in terms of varna, the more responsibility he should bear for his misdeeds. Thus Manu says: When another common man would be fined one kaarshaapana, the king shall be fined one thousand; that is the settled rule. In (a case of) theft the guilt of a 'Suudra shall. be eight-fold, that of a Vaisya sixteen fold, that of a Kshatriya two-andthirty fold, that of a Braahm.na sixty-four fold, or quite a hundred fold, or (even) twice four-and-sixtyfold; (each of them) knowing the nature of the offence. The system of awarding punishments on the basis of varna contravened the concept of equality of all human beings as propounded by the Vedas. The discriminatory system of inflicting punishments and contradictory provisions in different legal literature made the criminal justice system defective and confusing.

To discourage crime and to punish the criminals, Indians from very early times gave very special powers to rulers of the state. But it is impossible to check such tendencies absolutely and for various reasons social, economic and political, people challenged the norms of the society. The ancient Hindu Law givers laid down that punishment must be regulated by consideration of the motive and nature of the offence, the time and place, the strength, age, conduct, learning and economic position of the offender and above all, by the fact whether the offence was repeated. Dharamshaastra and Arthshastra show to us a more full fledged judiciary. Dharamshaastra and Nitishastra find the King as a fountain of justice. He had to spare a certain time to adjudicate the cases.

The essential duty of government was the maintenance of law and order. This was broadly defined to include the maintenance of social order as well as preventing and punishing criminal activity. An integral part of the Arthashastra was the dandaniti, the enforcement of laws through sanctions or punishments, which was a primary responsibility of the state While this may seem to reflect the principles of the modern 'positivist' state, other references of Kautilya to the legal 'process' confirm his links to the traditional legal system. Any matter in dispute was to be judged according to the four bases of justice. These, in order of increasing importance, were Dharma, Evidence, Custom, Royal edicts or promulgations.

In the event of a disagreement between custom and the Dharmashastras, or between the evidence and the Shastras, the matter, according to Kautilya, was to be decided in accordance with Dharma. Whenever there was a conflict between the Shastras and the written law based on Dharma, then the written law was to prevail.

Verse 3.1.38 of Kautilya's Arthashastra also laid down that Judges were called 'Dharmastha' upholder of Dharma, indicating that the ultimate source of all law is Dharma. Kautilya also recognized that the customary law of a people or a region was also relevant, in addition to which was law as promulgated by the king. 'When all traditional codes of conduct cease to operate due to disuse or disobedience, the king can promulgate written laws through his edicts, because he alone is the guardian of the right conduct of this world'.

Therefore, it can be summerised that the institutions of the criminal justice administration had taken their roots during the Vedic period in India. The system gradually developed and during the Mauryan period a welldefined criminal justice system had come into existence as described in the Arthashashtra. The punishments during ancient India were cruel, barbarous and inhuman. As regards the procedure and quantum of the punishments there were contradictions between various Smritis and in certain cases even among the provisions found in one Smriti itself. Later on it was the institution of state which took control of administration and as a guardian of the people took upon itself the right to punish the offender. Crime began to be classified and penal laws were enacted to deal with criminals.

\section{Rights of Arrested Persons in Ancient India}

However, there are not many direct evidences of the laws regarding the rights of the arrested persons in ancient India but the study of the concepts of state, administration of justice, law and police administration shows some hints of humanistic approach towards the arrested persons or prisoners. The society or individuals as has already been discussed were more inclined towards the righteousness than committing any wrong. The theory of rebirth loomed large in the minds of the people as they believe that all the sins done in this birth will have to be punished in next birth in any way. Therefore they preferred to live moral life as Atharva Veda also describes, Man is not an individual. He is a social organism. God loves him only who serves others being: men, cattle and other creatures. His glory lies in being a member of a big family

Even ancient criminal jurisprudence recognized that criminals were not born but made. These factors might be corresponding to the modern era such as social and economic, may be due to erosion of moral values by parental neglect, stress of circumstances or doing a criminal activity in spur of heat of a moment. The purpose of penology seemed to make an offender a non-offender. Ancient Smiritis writers envisaged these ideas. The ancient 
Smritis writers appropriately paid consideration to individuality of the offender. The Smritis writers in their writings had referred the release of offenders on account of good conduct and integrity of character, which seems to sustain the recent concept of Probation.

\section{Rights of an Accused in Ancient Times}

Ancient Hindu Legal System has the oldest ancestry of any known system of jurisprudence. In ancient times the 'Rule of Dharma' was prevailing in India. Indian concept of 'Dharma' was wider than the concept of 'Rule of Law' of England and even wider than American 'Due process clause'. Because it did not only requires what is just and legal but it also requires what is moral and natural as per dicta laid in 'Neetisashtras'. Our ancient writers had also practically recognized the ideal of perfect development of the individual to the full development of the society when they laid down that it was the business of the state to promote Dharma, Artha, Karma and Moksha.

Should there be no ruler to wield punishment on earth, says the Mahabharta (c. B. C. 6oo-A. D. 200), "the stronger would devour the weak like fishes in water. It is related that in days of yore people were ruined through sovereignlessness, devouring one another like the stronger fishes preying upon the feebler." In the Manu Samhita likewise we are told that "the strong would devour the weak like fishes... The Ramayana also describes the non state region as one in which "people ever devour one another like fishes." And a few details about the conditions in this non state are furnished in the Matsya-Purana.

Arrest is a judicial process of a court wherein an accused is taken into custody. In ancient India the arrest were of different kinds. There are references of Local arrest, Temporary arrest and arrest amounting to inhibition from travelling and arrest relating to his work. However there seemed to be humanistic approach in arrest also as certain category of persons were granted immunity from being arrested. Brihaspati mentioned some as:-

1) Engaged in study, 2) about to marry, 3) sick, 4) one afflicted by sorrows, 5) insane, 6) infant, 7) intoxicated, 8) very old man, 9) woman, etc.

Even Narada has mentioned that the following persons should not be arrested:

(1) About to marry, 2) tormented by illness, 3) about to offer sacrifice, 4) one afflicted by calamities and 5) minor. Even then sometimes the policemen however were very ruthless in their dealings with persons with suspicious movements and tried to extort confession by showing enormous cruelty which sometimes resulting death of criminals. Torture was also a method of punishment. In order to extract truth from the parties the court adopted the policy of persuasion, but if they failed, the accused was beaten with harsh canes. But humanistic approach towards offenders seemed alive as the traces of police officers being punished for violating their duties are found and it included also arresting a wrong person who otherwise should not have been arrested. Offences and misconduct committed by police officers, Jail Superintendent and other public servants were taken very seriously and severe punishments were prescribed. It was provided that the judges who passed unjust order, or took bribes, or betrayed the confidence reposed in them, should be banished.

Kautilya who was having very first hand knowledge regarding working and sorry state of affair has mentioned that the officers of the lock-ups where under trails and convicted persons were kept, who caused unnecessary inconvenience to the prisoners, behaved cruelly and rudely with them and extorted money from them or molested lady inmates were liable to various kinds of punishments. Obstructing prisoners in their daily avocations such as sleeping, sitting, eating or excreting was punishable with fines ranging from three panas and upwards. Even harassing prisoners in lock ups by removing him frequently from one room to other without informing the proper authority was fined twenty four panas and for torturing unjustly forty-eight panas. Depriving him of food and water with ninety six panas and for death causing by torture, one thousands panas.

Kautilya prescribed fines for misbehaving with ladies in prison houses also. The punishment was prescribed according to the status of lady molested.

Immunity from punishment based on humanitarian grounds was applicable irrespective of caste consideration. Yajnavalkya has mentioned that an old man over eighty, a boy below sixteen, woman and persons suffering from diseases were given half prayaschita. Likewise a child below five commits no crime. Kautilya was in favour of granting immunity from punishment to a minor.

Ashoka emphasised the human aspect of the judicial administration. He called upon the NagaraVyavaharakas (city Judges to see that the torture or imprisonment should not lead to accidental death of the accused. He was also of opinion that citizens were not imprisoned or tortured without sufficient reasons. Even self defence was prevalent as protecting himself, woman and Brahman was not an offence. Brihaspati mentions particularly that if anyone kills aggressor to save his life, commits no sin. Even killing in reaction to provocation was not deemed as offence. Right of self-defence existed during ancient India. The law provided: "A person can slay without hesitation an assassin who approaches him with murderous intent. By killing an assassin the slayer commits no offence. A person has a right to oppose and kill another not only in self-defence but also in defence of women and weak persons who are not in a position to defend themselves against murderous or violent attack. Even killing a Brahman in exercise of such a right is no offence." As per Katyayana no blame is attached to one 
who kills wicked men who are about to kill a person, but if they have desisted from their evil act of killing, they should be captured and not killed.

Manu in Manusmriti and Brahaspati in his Dandabheda Vyavastha referred that a gentle admonition should be administered to a man for light offence.

P. K. Sen has pointed out in his Tagore Law Lectures on "Penology Old and New" that the directions given by the ancient law-givers in the matter of punishment compare favourably with the advanced modern systems as regards the relevance of the objective circumstances attendant on the commission of the crime and the subjective limitations of offenders.

Yajnavalkya, laid down that having ascertained the guilt, the place and time, as also the capacity, the age and means of the offender, the punishment should be determined and if possible the man should be released if after putting into observation maintains good character and conduct. Kautilya, in his Arthashastra advised the king to award punishment which should neither be mild nor severe. Even Maurya rulers were in favour of mild punishment. One of the pronouncements of the emperor Ashoka contains provision for remission of punishment. $\mathrm{He}$ advised his officers to examine and reduce punishment awarded to prisoners after due consideration of circumstances which substantially coincides with those mentioned by Smriti writers.

Generally going through the procedure prevailing in ancient India it can be said that the following rights were available for individual offender

1. Right to engage counsel

2. Right to appeal

3. Right to examine witnesses

It was prescribed that the examination of witnesses should not be delayed. A serious defect, namely, miscarriage of justice, would result owing to delay in examination of witnesses. Witnesses were under legal compulsion to give evidence before the court. Failure to appear before the court entailed heavy penalty. Failure to give evidence amounted to giving false evidence. Perjury, i.e. the act of giving false evidence, was considered a serious offence and punishment was prescribed for it. The entire wealth of a person, who cited false witnesses out of greed, would be confiscated by the King, and in addition he would be externed. The party whose witnesses deposed against him could examine further and better witnesses to prove his case as well as to prove that the witnesses examined earlier were guilty of perjury.

If any person was dissatisfied with the judgment, and thought that the case had been decided in a way contrary to justice, he might have it re-tried on payment of a fine. Narada says, "when a lawsuit has been judged without any previous examination of witnesses (or other evidence), or when it has been decided in an improper manner, or when it has been judged by unauthorised persons, the trial has to be renewed." An appeal also lay from the decision of an inferior court to a higher tribunal, where the whole case was re- tried.

Fiehan a traveler during the Gupta period has mentioned that king governs without decapitation or other corporeal punishment.

\section{Penology and Humanistic Approach in Ancient India}

The great drawback of the State in Ancient India was that the rights of man as man were not fully recognized. Individuals had rights and duties not as component parts of the body politic but as members of estates or classes in society; and consequently, the rights and obligations varied according to the class to which the individuals belonged. The practice of indecent behavior with arrested or suspected persons by law enforcement agencies is an age old phenomenon and has been there in one way or another. Maharshi Ved Vyas's paropkaraya punyam papam parpidanam, meaning thereby promotion of well being of other is virtue and infliction of pain is sin, laid the acid test for explaining punya and paap. These high ideals of life and philosophy of saints and sages were followed in cases of prisoners and accused in ancient India. However in second phase of the ancient Hindu period torture was common and punishment for that was also prescribed in various Hindu scriptures. In fact the penology had its roots in ancient India. It can be traced in the earliest Vedic period of Indian History. It developed under the connotation of Dandaniti which literally means principles of punishment. The concept of rule of law and the administration of justice had been known to exist in India ever since the Vedas come to be recognized on the crazy epitome of Dharma. Police brutalities or torture was common in this period and was practiced by police on prisoners and torture under the order of the King was not uncommon. Next was the age of law and philosophy (800-320 BC) during which Manu, Yajnavalkvya, Kautiliya, Gautam were some important law givers. In the Manusmriti there were enough instances where harsh punishment was prescribed for the violators of law. The ancient literature however also hints at some humanistic approach towards offender as Manu held that after considering the inclination in the offenders, his antecedents and capacity punishment should be given. Kautilya in his Arthashastra has also stated that a suspect should not be put under arrest after a lapse of three days from the commission of crime when no direct evidence was found against him. The suspects were kept under vigil as the prerogative was to prevent the crime. 
King Ashoka, in his Edicts has clearly mentioned that "In affairs of administration there might be some persons who would get imprisonment and coercion, there also might occur accidental death in prison and many imprisoned persons might suffer long. In that case you must strive to deal with all of them impartially; the attributes which are not conducive to impartial dealings are malignity, irascibility, harshness and hastiness, lack of practice, indolence and weariness. You all must strive, so that these attributes may not be there in you. At the root of all impartial dealings lie the absence of anger and avoidance of hurry....The judicial officer of the capital must strive at all times for this; and they should inflict sudden imprisonment or sudden coercion on people. For this purpose I would be sending on quinquennial tours the Mahamatras who would not be harsh and irascible and would be soft and gentle in dealings." Mahamatras were important ministers and were working as censors of public morals. These officers were empowered to reduce penalties and revise the sentences of imprisonments or even grant release on humanitarian grounds.

The ancient India witnessed customs of ordeals also that some times were very brutal in performance. But it was practiced only where the accused person is not identified or there were no evidence against that person. Therefore the ordeals were performed to prove their selves innocent. This traditional experimental jurisprudence remained in existence for long time at remote areas but with the development of concept of governance through King as head and assistance by his ministers and police functions, it was reduced to nullity. However, generally there is a notion that the primitive man had not known anything like human rights. With the advent of civilization one might have hoped that some respect for human rights would emerge which seemed to be have developed with or relates its development with the Industrial Revolution. A theory prevailed that man is endowed by birth with certain inalienable rights of which right to life, liberty and property are sacrosanct and after the conclusion of the Second World War movement for securing human rights to all gained strength."

\section{Conclusions}

Ancient India had witnessed a drastic transformation of laws as initially, the Law or Dharma, as propounded in the Vedas was considered supreme in ancient India for the King had no legislative power. But gradually, this situation changed and the King started making laws and regulations keeping in view the customs and local usages. So long as the territory was small, the form of administration was more or less democratic; but as the size of the territory grew large, it was found necessary to adopt a system in which political powers were concentrated in the hands of the Head of the State assisted by a Council of Ministers and a trained bureaucracy. Even ancient criminal jurisprudence recognized that criminals were not born but made. The purpose of penology seemed to make an offender a non-offender. Ancient Smriti writers envisaged these ideas. The ancient Smriti writers appropriately paid consideration to individuality of the offender. The Smriti writers in their writings had referred the release of offenders on account of good conduct and integrity of character, which seems to sustain the recent concept of Probation. However there are evidences of torture against the arrested persons or accused persons but the rights of arrested persons in the form of fair trial, right of appeal, right to examine witnesses and right of being represented by a counsel, right against torture are found in many scripts during ancient India. Brihaspati and Narda had mentioned certain grounds where there was immunity from being arrested. Immunity from punishment based on humanitarian grounds was applicable irrespective of caste consideration. Therefore, amidst all other irregularities or harshness of administration of justice, no doubt the humanitarian laws existed since ancient time and developed with the progress of the society.

\section{References:}

[1]. Human Rights, Stanford Encyclopedia of Philosophy,

[2]. The United Nations, Office of the High Commissioner of Human Rights, What are human rights?, Retrieved September 14, 2014 from http://www.ohchr.org/en/issues/pages/whatarehumanrights.aspx

[3]. Dalbir Bharti, The Constitution and Criminal Justice Administration, 42(APH Pub. Delhi, 2002)

[4]. Alakh Niranjan Singh and Prabhakar Singh, "What Can International Law Learn from Indian Mythology, Hinduism and History?" 2 JEAIL 246 (2009)

[5]. S. Radhakrishnan, The Heart of Hindustan, 24 (Natesan\& Co. Madras, 1932)

[6]. Robert Lingat, The Classical Law of India, 8 (The Thompson Press (India) Ltd., 1975)

[7]. L. Basham, The Wonder that was India, 114 (Rupa\& Co., New Delhi, Third Revised Edition)

[8]. Pramathanath Banerjea, Public Administration in Ancient India, 31 (Mcmillan\& Co. 1916)

[9]. Satya Prakash Dash,, Constitutional and Political Dynamics of India, 140 (Sarup and Sons Delhi, 2004)

[10]. Frederic B. Underwood, Aspects of Justice in Ancient India, 5 JCP 271 (1978)

[11]. S. Altekar, State and Government in Ancient India, 245-246 (MotilalBanarsiDass Delhi, 2001)

[12]. Manu, VII. 20. George Buhler (trans.) The Laws of Manu 219 (Dover Press Publications, Inc., New York, 1969)

[13]. P. K. Sen, Penology Old and New, 112 (London : Longmans, Green, 1943)

[14]. L. N. Rangarajan (ed), Kautilya, The Arthashastra, 14 (Penguin Books India, Pvt. Ltd. 1992)

[15]. Ashish Kumar Das and Prasant Kumar Mohanty, Human Rights in India, 4 (Sarup and Sons New Delhi, 2007)

[16]. M. K. Sharan, Court Procedure in Ancient India, 1(Abhinav Publication, New Delhi, 1978)

[17]. W. Mabbett, The Date of the Arthshastra, 84 (Journal of American Oriental Society), 162-169 April-June (1964)

[18]. D. Mayne, A Treatise on Hindu Law and Usage. iii (Preface to First edition, Higginbotham Madras 11th edition, 1950)

[19]. Benoy Kumar Sarkar, The Hindu Theory of the State, 36 Pol. Science Quarterly 80 (1921) 
[20]. Jullius Jolly, The Minor Law Books Trans., Part I, Narada. Brihaspati, 188 (Oxford The Clarendon Press, 1889, reprinted in 2008 by Forgotten Books).

[21]. R. K. Mukherjee, Ancient IndianEducation, 135 (Delhi: MotilalBanarsiDas, Delhi, 1969)

[22]. Sunil. K, Bhattacharya, Juvenile Justice-An Indian Scenario, 56 (Regency Publication, New Delhi, 2000)

[23]. David G. Mandelbaum, Society in India, 221 (Popular Prakashan Ltd, Bombay, 1998).

[24]. JaishreeJaiswal, Human Rights of Accused and Juveniles: Delinquent in Conflict with Law, 50-51 (Eastern Books Corporation, 2005)

[25]. Surender Singh, Rural Development and Human Rights in India: A Critique, in P. M. Katare and B. C. Barik, Development Deprivation and Human Rights Violation, 109 (Rawat Publication Jaipur, 2002).

[26]. S. K. Ghosh, The Outcry of Police Brutality, 34 (Aashish Pub. Delhi,1983)

[27]. Nitai Ray Chaudhary, Indian Prison Law and Correction of Prisoners, 23 (Deep \& Deep Pub. Delhi, 2002)

[28]. Ven. S. Dhammika, ,The Edicts of King Ashoka, An English Rendering Wheel Publication Sri Lanka 1993. Retrieved from http://www.accesstoinsight.org/lib/authors/dhammika/wheel386.html (visited on 23rd Oct. 2010)

[29]. Paras Diwan and Peeyushi Diwan, Human Rights and the Law, Universal and Indian, 1 (Deep \& Deep Publication Delhi, 1996) 